\title{
AN EMISSION INVENTORY FOR THE CENTRAL EUROPEAN INITIATIVE 1988
}

Z. Klimont, M. Amann, J. Cofala, F. Gyárfáš, G. Klaassen, and W. Schöpp

International Institute for Applied Systems Analysis

Laxenburg, Austria

RR-94-10

September 1994

Reprinted from Atmospheric Environment Vol. 28, No. 2, pp. 235-246, 1994. 
Research Reports, which record research conducted at IIASA, are independently reviewed before publication. Views or opinions expressed herein do not necessarily represent those of the Institute, its National Member Organizations, or other organizations supporting the work.

Reprinted with permission from Atmospheric Environment, Vol. 28, No. 2, pp. 235-246, 1994.

Copyright (C)1994 Elsevier Science Ltd.

All rights reserved. No part of this publication may be reproduced or transmitted in any form or by any means, electronic or mechanical, including photocopy, recording, or any information storage or retrieval system, without permission in writing from the copyright holder.

Printed by Novographic, Vienna, Austria. 


\section{Preface}

Reliable knowledge of the sources and magnitudes of emissions of air pollutants is an absolute requirement for any assessment of air pollution for research and policy purposes.

A few years ago, accessible information on pollution in many eastern European countries was sparse. Nevertheless, using IIASA's position as an East-West institute, IIASA's Transboundary Air Pollution Project developed the RAINS model for the integrated assessment of international strategies to reduce transboundary air pollution in Europe. With the help of many collaborators in IIASA's member countries, the databases have been filled with the best information available at that time.

Now the situation has changed and environmental information is abundant. However, serious questions remain as to the quality and the international consistency of national data. Again, IIASA has used its scientific network to establish the first harmonized inventory of air pollutants' emissions in the region of the Central European Initiative. The task was facilitated by the fact that most countries participating in this new initiative are also members of IIASA.

Providing detailed information on emissions in the heart of Europe this inventory will serve as a valuable basis for the design of effective strategies to reduce air pollution in Europe.

Peter E. de Jánosi

Director 



\title{
AN EMISSION INVENTORY FOR THE CENTRAL EUROPEAN INITIATIVE 1988
}

\author{
Z. Klimont, M. Amann, J. Cofala, F. Gyárfáš, G. Klaassen and W. Schöpp \\ International Institute for Applied Systems Analysis (IIASA), A-2361 Laxenburg, Austria
}

(First received 15 May 1993 and in final form 11 July 1993)

\begin{abstract}
This paper presents the first consistent inventory of emission of sulphur dioxide $\left(\mathrm{SO}_{2}\right)$, nitrogen oxides $\left(\mathrm{NO}_{x}\right)$, particulate matter $(\mathrm{PM})$, and carbon dioxide $\left(\mathrm{CO}_{2}\right)$, for the countries co-operating in the Central European Initiative: Austria, Croatia, Czechoslovakia, Hungary, Italy, Poland and Slovenia. The inventory is based on national and regional statistics as well as on information received from collaborating institutions. National data has been verified and converted into a common format, consistent with the database used by the European Environmental Agency and the European Community (the "CORINAIR" system). The inventory describes emissions in the year 1988, before the restructuring process began in former socialist economies. Data has been collected on the national level, for administrational units and for large point sources. The database on point sources contains specific information on 400 large plants in the region (e.g. capacity, commissioning year, fuel use, production, etc.).

Total emissions of $\mathrm{SO}_{2}$ in the CEI region in 1988 were 10.3 million tons, which accounts for $25 \%$ of total European $\mathrm{SO}_{2}$ emissions. The highest emission densities (more than $100 \mathrm{t} \mathrm{km}^{-2}$ ) are found in Northern Bohemia (Czech Republic) and Upper Silesia (Poland). The overwhelming majority of $\mathrm{SO}_{2}$ emissions (70\%) originates from combustion of domestic (brown and hard) coal. Across the region, $60 \%$ of $\mathrm{SO}_{2}$ is emitted from the large point sources identified in the study and over $50 \%$ of $\mathrm{SO}_{2}$ emissions from public power plants in the CEI region is produced in plants older than 20 years.
\end{abstract}

Key word index: Inventory, central Europe, emissions, air pollution, point sources.

\section{INTRODUCTION}

Central Europe maintains a central position on the continent not only in a geographical sense-various circumstances have also given it a central role in releasing harmful substances into the atmosphere. Reliable information on emission quantities is, however, still rare. Before the political changes of 1989/ 1990 environmental data was often considered confidential, providing room for vast speculations. After that time, access to information became possible; the quality and reliability of statistical material, however, are in many cases still reasons for concern, and the international consistency, and consequently the comparability, of the environmental data of this region has still to be established.

Several estimates of the emission levels of various air pollutants in East European countries on national level (Veldt, 1991; Pacyna, 1989; Pacyna et al., 1989) as well as for point sources (Pacyna, 1988) have already been performed. Although those studies covered generally all East European countries, the estimates were mainly based on western European experience and literature studies, and did not make use of the existing national inventory systems and expert know-

* CORINAIR is part of a comprehensive Programme CORINE (COoRdination of INformation on the Environment), providing a sound basis for all kinds of environmental information (land use, air pollution, waste, water pollution, etc.) in Europe (CEC, 1991). ledge available at many environmental institutes and agencies in the region.

The study described in this paper was carried out as part of the international activities of the Central European Initiative (CEI) which includes Austria, Croatia, Czechoslovakia, Hungary, Italy, Poland and Slovenia. National experts representing various institutions in concerned countries were actively involved in the process of collecting data as well as in verifying the final report. This paper summarizes the results of this work, i.e. an inventory of the emissions of sulfur dioxide $\left(\mathrm{SO}_{2}\right)$, nitrogen oxides $\left(\mathrm{NO}_{x}\right)$, particulate matter $(\mathrm{PM})$ and carbon dioxide $\left(\mathrm{CO}_{2}\right)$ for the year 1988 (Klimont et al., 1993).

\section{METHODOLOGY}

The CORINAIR* data-reporting format (CEC, 1988) has been adopted as the common standard for all European countries to fulfil their obligations within the Convention on Long-range Transboundary Air Pollution of the United Nations Economic Commission for Europe (UN/ECE). Recognizing this, a decision has been taken by all country experts involved in this study to establish a common CEI inventory in line with the CORINAIR standards. This decision will fully apply to the upcoming CEI inventory for the year 1990, for which data collection is currently being performed.

However, existing national emission databases (e.g. for the year 1988) in most of the CEI countries are not fully compatible with the CORINAIR standards. Analysis has shown that an exact transformation of the existing databases 
into the CORINAIR format would create major difficulties in some countries. Consequently, a procedure has been developed to establish a common data structure, as far as possible consistent with the envisaged CORINAIR' 90 system, into which all existing national databases could be converted.

The CEI'88 inventory makes a distinction between emissions from large point sources (LPS) and from dispersed area sources. In order to identify the largest single polluters in the region and subsequently to design cost-effective strategies to reduce emissions, the emissions from large point sources are collected on a plant basis together with a number of technoeconomic features of the emission sources. Large point sources (identified in this study) include emitters fulfilling at least one of the following criteria:

- power plants with a capacity of more than $50 \mathrm{MW}_{\text {therm }}$.

- oil refineries,

- plants in which sulfuric acid or nitric acid is produced,

- plants which discharge into the atmosphere more than 1000 tons of $\mathrm{SO}_{2}$ or $\mathrm{NO}_{x}$ or particulate matter per year.
For each of these sources a set of basic information is stored in the CEI'88 database. For the largest emitters, depending on the availability of information, a variety of additional characteristics are contained (e.g. location, construction year, type and number of boilers, installed capacity and its utilization, fuel use and its quality, production, and emissions of air pollutants). Unfortunately, this in-depth information is not yet available for all large point sources across the CEI region. Area sources, covering all remaining emissions not counted under the large point sources category, should provide important information on the total amount of emissions in a certain region, information that is relevant to analyse the environmental impacts of air pollution. The data are stored as national totals, i.e. describing emissions from the individual countries of the CEI region, as well as for regional levels (according to the NUTS-Nomenclature des unités territoriales statistiques - levels as defined by the Statistical Office of the European Communities EUROSTAT (EUROSTAT, 1991, 1992)).

On a national level, emissions are aggregated into major activity groups (economic sectors), as far as possible com-

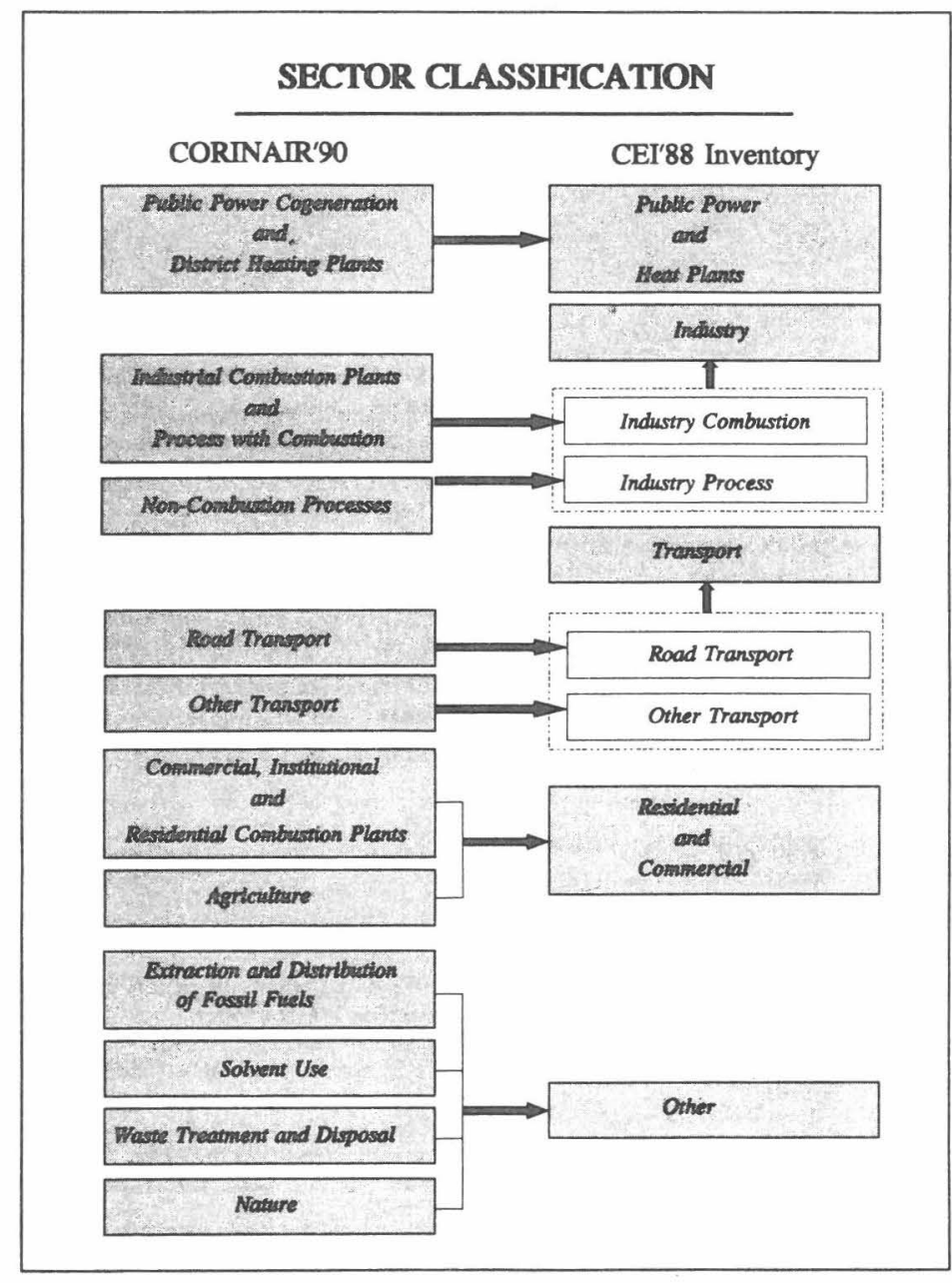

Scheme 1. Sector classification of the CORINAIR' 90 and CEI' 88 inventories. 
patible with the CORINAIR'90 inventory (Scheme 1). Unfortunately, lack of information did not allow a consistent sectoral disaggregation on a regional level. Only a few of the countries considered could provide appropriate data.

\section{RESULTS AND DISCUSSION}

Analysis of national and regional emissions

The aggregated results of the emission account performed in this study are displayed in Table 1. On a national level, emission densities vary for $\mathrm{SO}_{2}$ by as much as a factor of 19 , and for $\mathrm{NO}_{x}$ and particulates

Table 1. National total emissions for the countries of the CEI region in 1988

\begin{tabular}{lrrrc}
\hline Country & $\begin{array}{c}\mathrm{SO}_{2} \\
(\mathrm{kt})\end{array}$ & $\begin{array}{c}\mathrm{NO}_{x} \\
(\mathrm{kt})\end{array}$ & $\begin{array}{r}\mathrm{PM} \\
(\mathrm{kt})\end{array}$ & $\begin{array}{c}\mathrm{CO}_{2} \\
(\mathrm{mlnt})\end{array}$ \\
\hline Austria & 116 & 225 & 44 & 55 \\
Croatia* & 70 & 10 & 2 & - \\
CSFR & 2672 & 1109 & 1144 & 244 \\
$\quad$ Czech Republic & 2066 & 858 & 840 & 180 \\
$\quad$ Slovak Republic & 606 & 251 & 304 & 64 \\
Hungary & 1171 & 231 & 222 & 84 \\
Italy & 2216 & 1982 & 492 & 443 \\
Poland & 3827 & 1363 & 2145 & 454 \\
Slovenia & 210 & 50 & 25 & 14 \\
CEI & 10,282 & 4970 & 4074 & 1295 \\
Europe† & 40,644 & 20,546 & - & $7250 \ddagger$ \\
\hline
\end{tabular}

* Emission data for Croatia includes only public power plants (Jelavic et al., 1992).

+ Total European emissions of $\mathrm{SO}_{2}$ and $\mathrm{NO}_{x}$ are estimated on the basis of the UN Economic Commission for Europe (ECE) data as of 1 Oct. 1992 (UNECE, 1992).

$\ddagger$ Total European $\mathrm{CO}_{2}$ emission estimation is based on information stored in the database of the Environmentally Compatible Energy Strategies Project at IIASA. by a factor of 4 and 21, respectively. In terms of population, the largest differences occur for $\mathrm{SO}_{2}$ emissions, ranging from about $200 \mathrm{~kg}$ per capita in the Czech Republic to $15 \mathrm{~kg}$ per capita in Austria. Similarly, a difference in GDP-related $\mathrm{SO}_{2}$ and $\mathrm{PM}$ emissions exists between, e.g. the Czech Republic or Poland and Austria by a factor of around 20. On the other hand, $\mathrm{NO}_{x}$ emissions per unit of GDP vary only by a factor of five.

Carbon intensity (ton $\mathrm{CO}_{2}$ per $\mathrm{PJ}$ energy input) in the former CMEA (Council of Mutual Economic Assistance) economies is 3-5-times higher than in Austria, Italy and Slovenia. It has to be noted that the high numbers of $\mathrm{NO}_{x}$ emissions in the Czech Republic and the Slovak Republic are subject to serious doubts because of the emission coefficients used to calculate $\mathrm{NO}_{x}$ emissions from power plants in these countries.

Within the CEI region the contribution of individual countries to overall emissions is strongly dependent on the pollutant (Fig. 1). For example, whereas the market economies of Austria and Italy contribute some $10-20 \%$ of the total CEI emissions of particulate matter and $\mathrm{SO}_{2}$, they release about $40 \%$ of the $\mathrm{NO}_{x}$ and $\mathrm{CO}_{2}$ emissions in this region.

The CEI' 88 inventory allows for a structural indepth analysis of national emissions. Important conclusions can be drawn from disaggregating national data according to the fuel types causing the emissions. As shown in Fig. 2, the overwhelming majority of $\mathrm{SO}_{2}$ emissions in the CEI region $(70 \%)$ originates from combustion of domestic (brown and hard) coal. In the Czech and Slovak Republics, Hungary and Slovenia, the burning of these fuels creates more than $75 \%$ of the total national $\mathrm{SO}_{2}$, in Poland as much as $90 \%$ of $\mathrm{SO}_{2}$

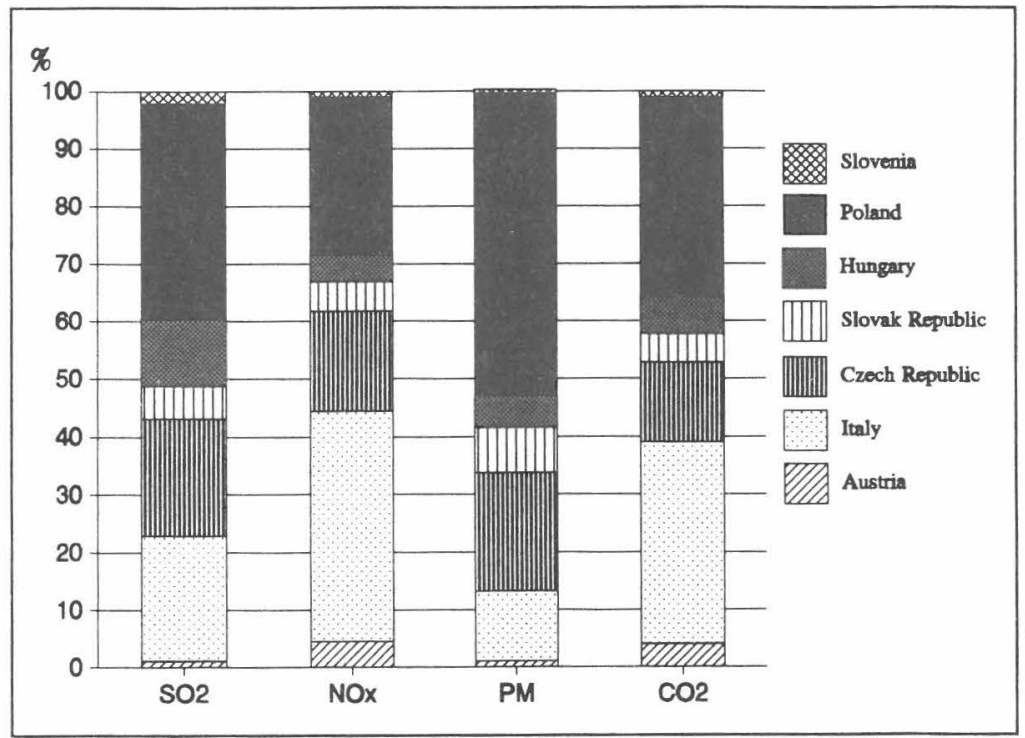

Fig. 1. National contributions to total CEI emissions. 


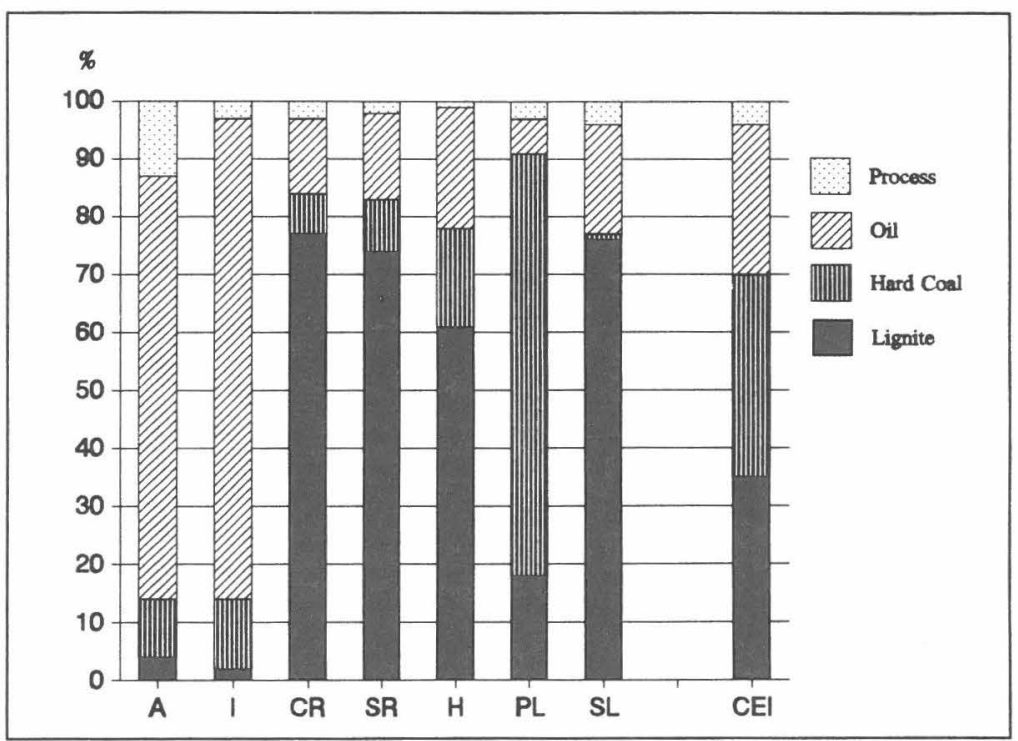

Fig. 2. $\mathrm{SO}_{2}$ emissions by fuels in the $\mathrm{CEI}$ region.

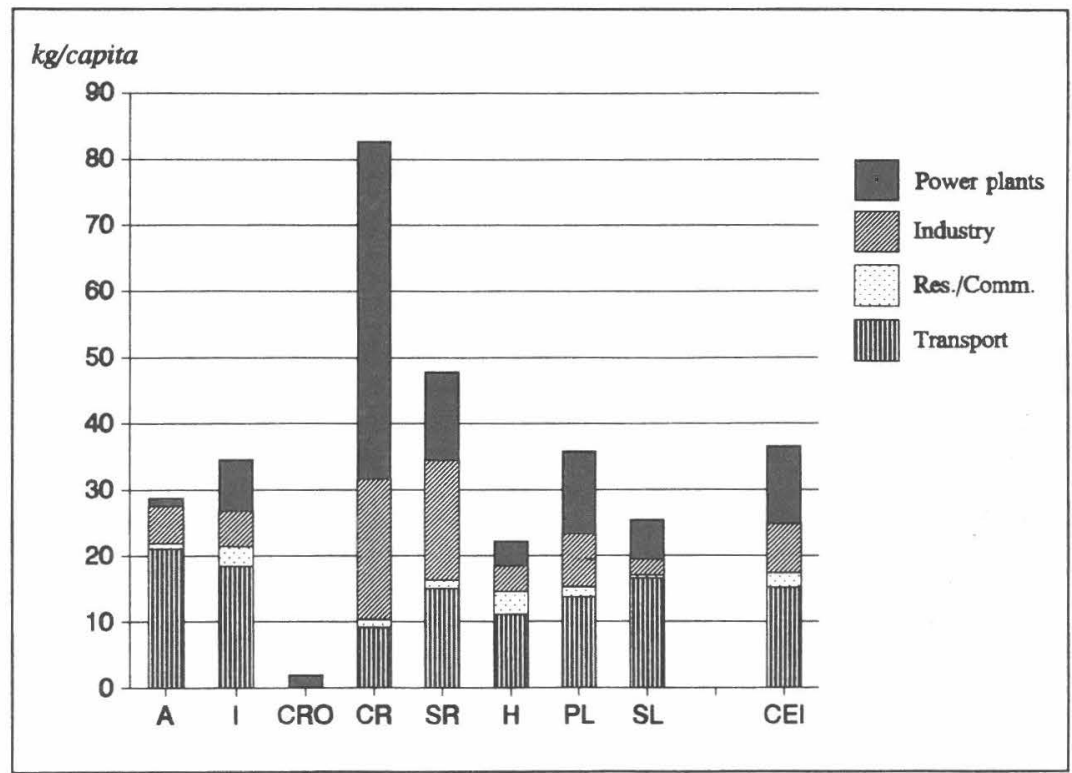

Fig. 3. Sectoral per capita emissions of $\mathrm{NO}_{x}$ in the $\mathrm{CEI}$ region.

emissions result from combustion of (domestic) solid fuels. On the other hand, in countries where solid fuels are to a large extent imported, i.e. in Austria and Italy, related $\mathrm{SO}_{2}$ emissions account for less than $20 \%$ of their national totals. As a consequence, it may be concluded that a simple fuel substitution policy in order to decrease emissions, i.e. replacing high-sul- phur hard coal by other forms of (imported) energy, would have significant economic effects on the domestic coal-mining activities in eastern European countries.

A similar situation exists for emissions of particulate matter. The high emissions specific to solid fuels are aggravated by the fact that, in contrast to western 
European standards, many power stations in the former CMEA countries are still operated without adequate equipment to capture particulates.

The contribution of western countries to total $\mathrm{NO}_{x}$ and $\mathrm{CO}_{2}$ emissions in the $\mathrm{CEI}$ region is substantially higher than their contribution to $\mathrm{SO}_{2}$ and PM emissions. Higher traffic density in Austria and Italy results in higher $\mathrm{NO}_{x}$ emissions (see Fig. 3). A similar situation is also present for carbon dioxide emissions. Higher $\mathrm{CO}_{2}$ emissions due to the energy intensity in the former CMEA countries are partly counterbalanced by higher transport emissions in western market economies.

\section{$\mathrm{SO}_{2}, \mathrm{NO}_{x}$ and $\mathrm{PM}$ emission densities}

The CEI'88 inventory also contains a database with $\mathrm{SO}_{2}, \mathrm{NO}_{x}$ and particulate matter emissions allocated to the territorial units. This section presents maps of the CEI region. The maps display the emission densities of the considered pollutants.

Figure 4 displays the emission densities of $\mathrm{SO}_{2}$ in the individual administrative regions throughout the CEI region. Area-related emissions range from below one ton of $\mathrm{SO}_{2}$ per $\mathrm{km}^{2}$ per year $\left(\mathrm{SO}_{2} \mathrm{~km}^{-2} \mathrm{yr}^{-1}\right)$ in Austria, northern Poland, and many regions in Italy to above 100 tons $\mathrm{SO}_{2} \mathrm{~km}^{-2} \mathrm{yr}^{-1}$ in Northern Bohemia and Upper Silesia. The major reason for this wide range can be derived from a comparison of the emission densities of area sources with those of point sources. Area source emissions show relatively little variations, with peaks in densely populated areas (e.g. in Prague, Warsaw, Budapest and Milan), and in districts around coal mines, where local coal is burned in small appliances (e.g. Northern Bohemia and eastern Hungary). Large point sources, however, can dominate total emissions in a region. The absolute peak occurs in Northern Bohemia (with more than 100 tons $\mathrm{SO}_{2} \mathrm{~km}^{-2} \mathrm{yr}^{-1}$ from LPS); many areas, however, have low or even no LPS emissions.

Regional densities of $\mathrm{NO}_{x}$ emissions show less variation than regional densities of $\mathrm{SO}_{2}$ emissions (Fig. 5). High emissions occur in many regions of Italy and in the industrialized areas of Poland and Czechoslovakia. The major source of $\mathrm{NO}_{x}$ emissions in most Italian regions is from area sources, only in a few regions (e.g. Gorizia, La Spezia) do point sources contribute substantially. In Czechoslovakia and Poland, point source emissions have higher shares in total regional emissions than in other CEI countries. The main reason for this is the higher motorization in western countries and the fact that in Czechoslovakia and Poland the number of large point sources identified (in this inventory) is larger than, for example, in Hungary, where individual data on industrial sources is missing.

Figure 6 shows the regional distribution of particulate matter emissions. The strong reliance on lowquality coal combustion without appropriate control technologies in the former CMEA (Council of Mutual
Economic Assistance) countries causes considerable emissions in this region, whereas in countries where high-efficiency electrostatic precipitators are standard equipment of coal-fired boilers, emission densities are significantly lower.

\section{Characterization of large point sources in the CEI region}

The CEI'88 emission inventory comprises a database with detailed techno-economic information on the large pollution sources in the region. Currently, this database identifies 402 individual sources. The locations and the emission levels of the individual large point sources of $\mathrm{SO}_{2}$ are displayed in Fig. 7.

Across the CEI region, $60 \%$ of $\mathrm{SO}_{2}$ is emitted from the large point sources. On the other hand, only about one-third of $\mathrm{NO}_{x}$ originates from these large emitters. The contributions of large point sources to total national emissions are shown in Fig. 8. In the majority of the CEI countries LPS contribute more than $60 \%$ to national sulphur dioxide emissions. The only exception is Austria, where a rigorous desulphurization program applied to large boilers lowered the contribution to about $25 \%$.

Out of the 402 large point sources identified in the CEI'88 inventory, 204 units belong to the category of public power plants. Thereby, the generation of electricity in those plants causes almost half $(46.3 \%)$ of the total $\mathrm{SO}_{2}$ emissions of the region. Consequently, power plants are major candidates for reducing $\mathrm{SO}_{2}$ emissions in the region. However, any effective emission reduction strategy should not only focus on environmental aspects alone, but also consider the broader economic context, in particular the energy efficiency of national economies, the age and technical performance of the equipment, and changes in energy demand caused by structural changes in the economy.

With the information collected during the study for the large point sources important conclusions for potential restructuring processes can be drawn. As an example, Fig. 9 displays national $\mathrm{SO}_{2}$ emissions in public power stations according to the age classes of the boilers, i.e. differentiated according to the commissioning year of the source. Over $50 \%$ of $\mathrm{SO}_{2}$ emissions from public power plants within the CEI region is produced in plants older than 20 years. An important exception is Austria where power stations older than 20 years, using sulphur-containing fuels, operate only in peak mode contributing only $5 \%$ to the $\mathrm{SO}_{2}$ emission. In Hungary, on the other hand, more than $80 \%$ of the $\mathrm{SO}_{2}$ was produced in boilers older than 20 years.

In general, boilers usually reach the end of a technical lifetime within $20-40$ years. Consequently, it does not seem promising to promote strategies for retrofitting plants older than 20 years with desulphurization equipment, but, if economically feasible, it might be preferable to replace the entire plant by new installations. Such new installations will also have a 


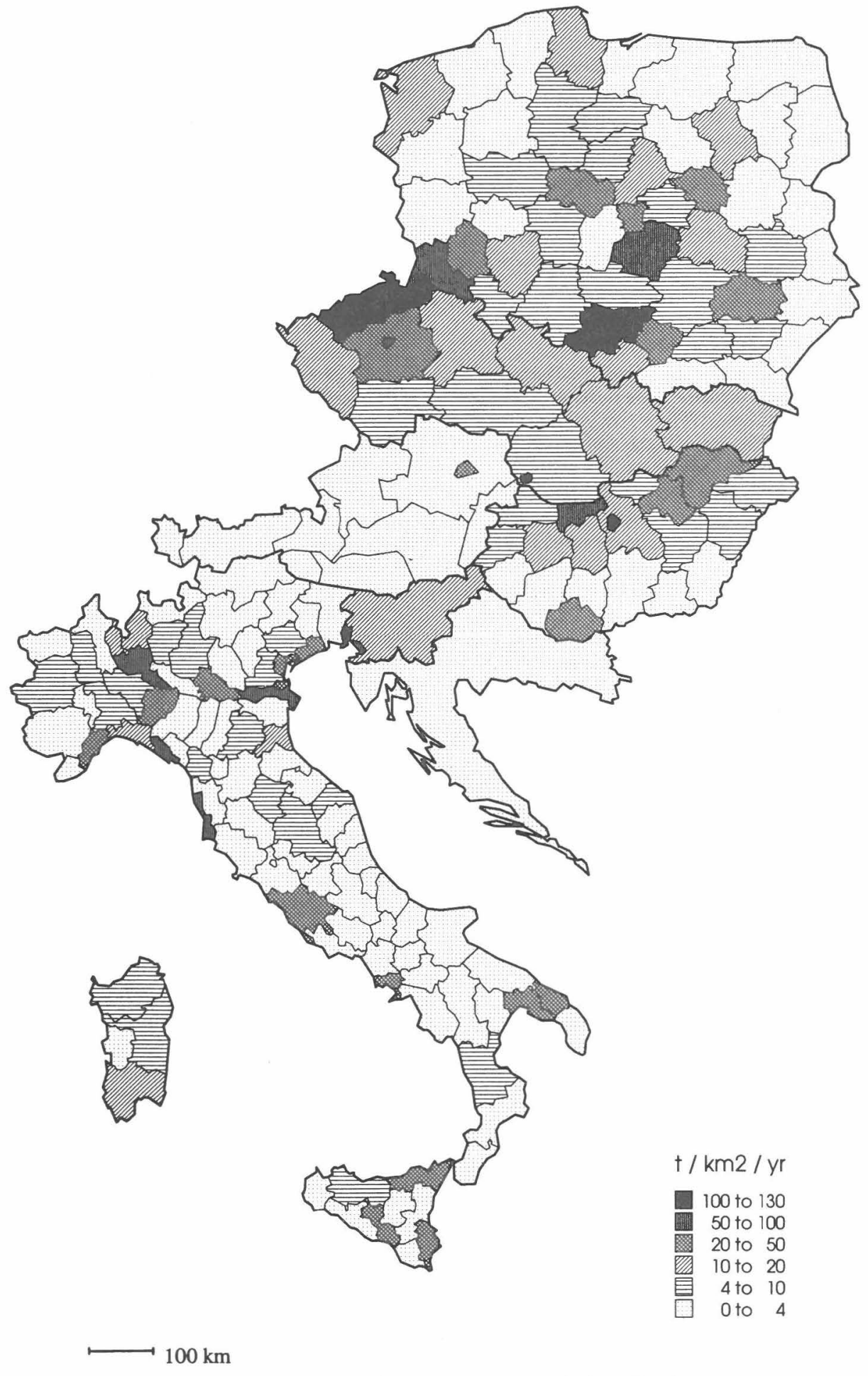

Fig. 4. Regional $\mathrm{SO}_{2}$ emissions from all sources in the CEI region. 


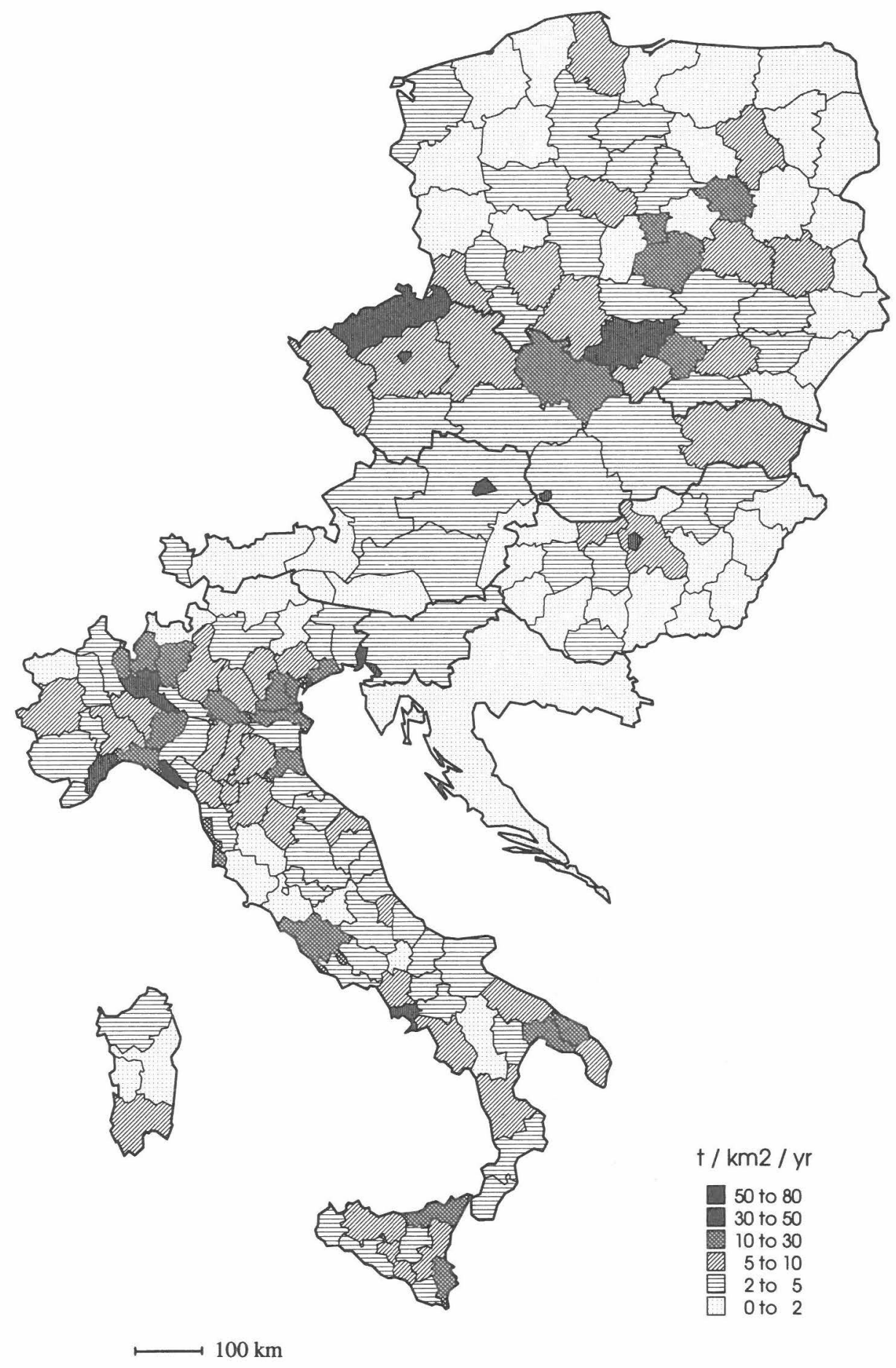

Fig. 5. Regional $\mathrm{NO}_{x}$ emissions from all sources in the CEI region. 


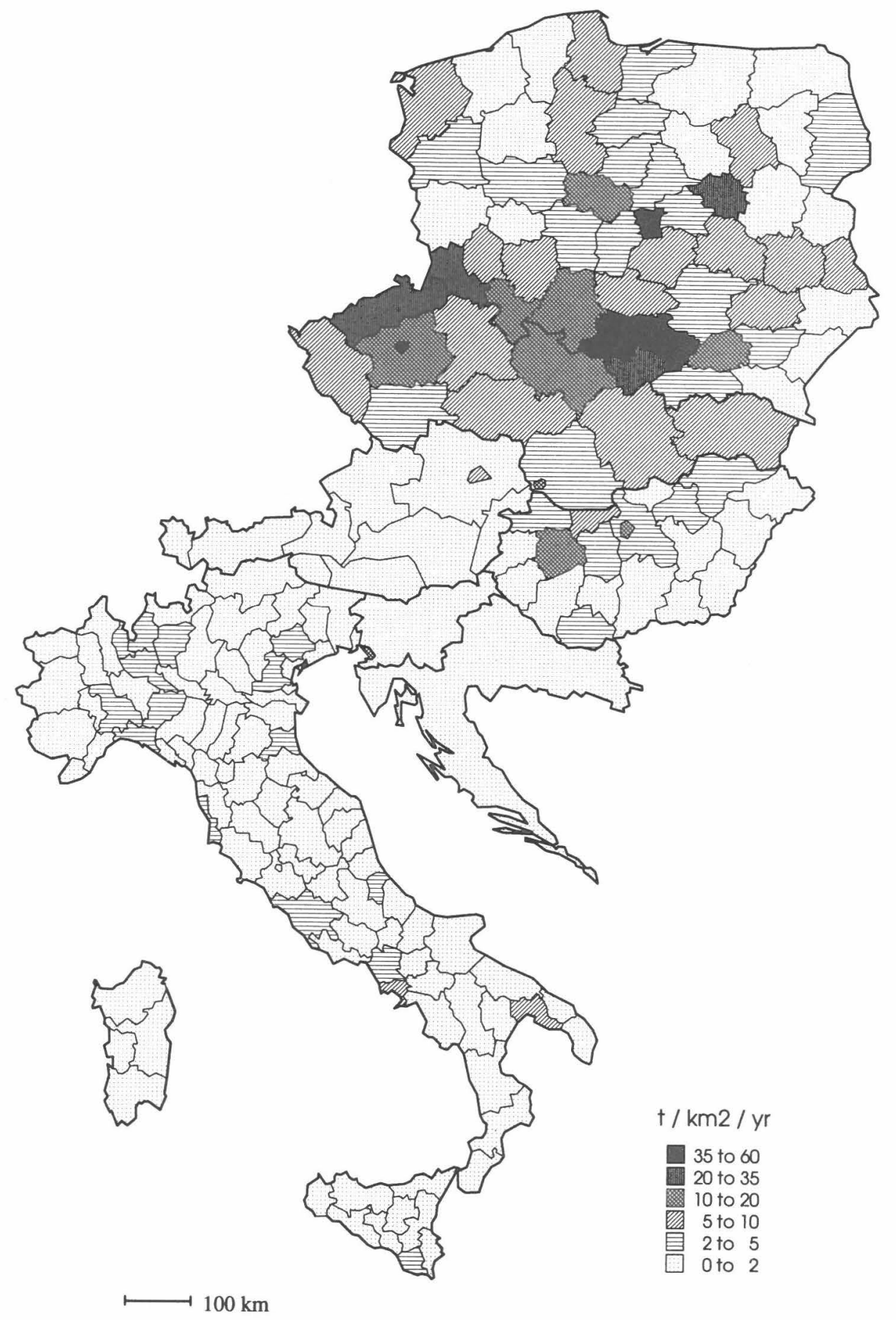

Fig. 6. Regional PM emissions from all sources in the CEI region. 


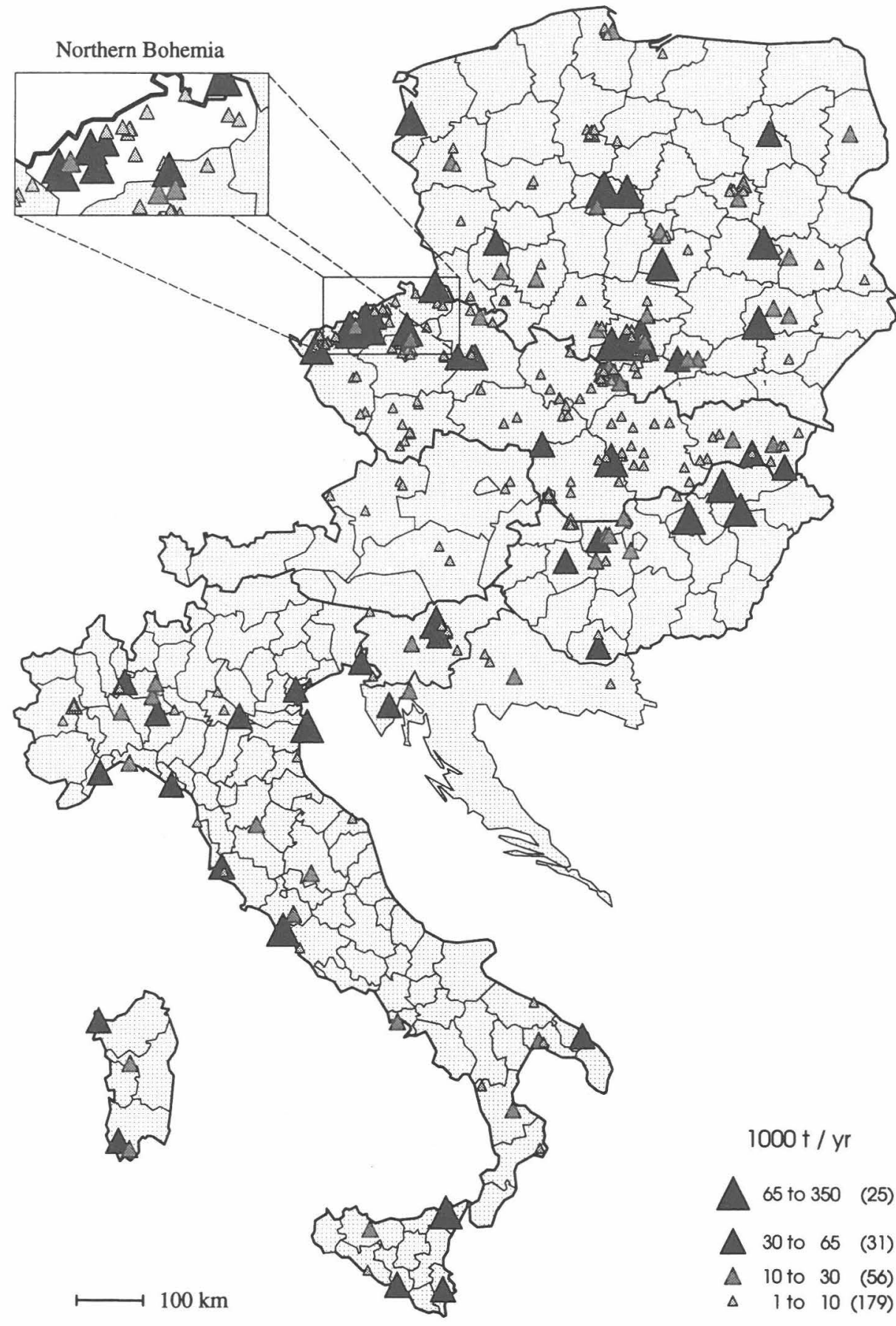

Numbers in parentheses indicate the number of LPS in each range

Fig. 7. Locations of large point sources of $\mathrm{SO}_{2}$ emissions in the CEI region. 


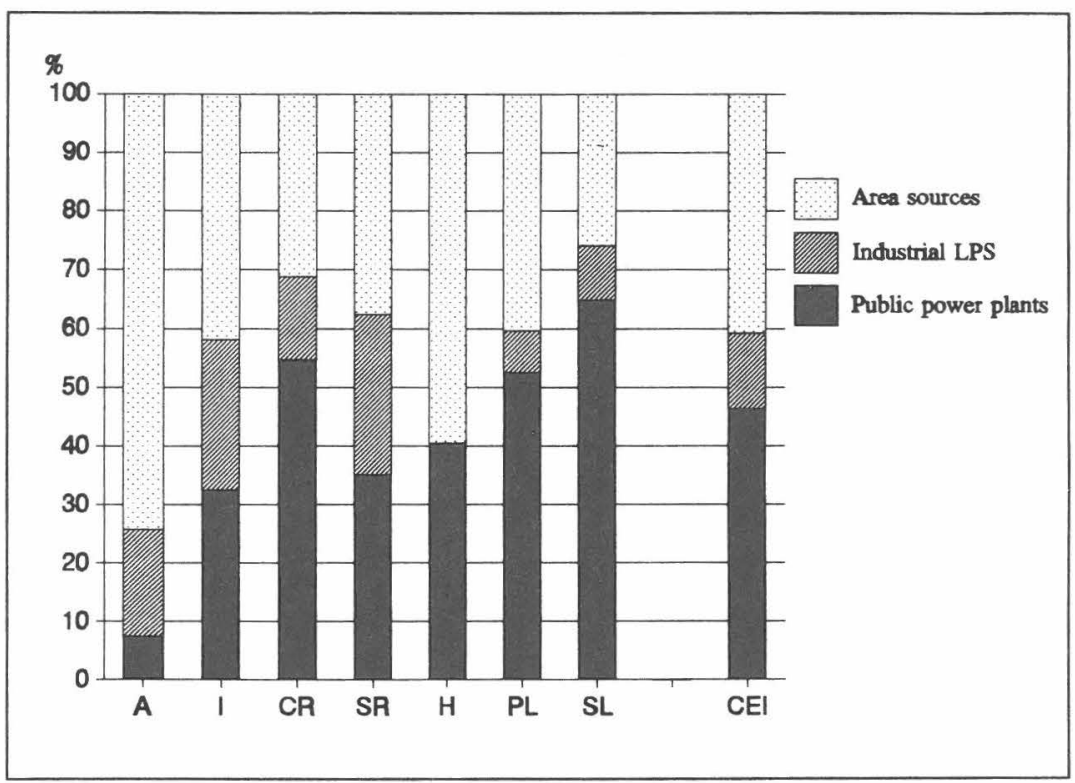

Fig. 8. Share of large point sources in national $\mathrm{SO}_{2}$ emissions.

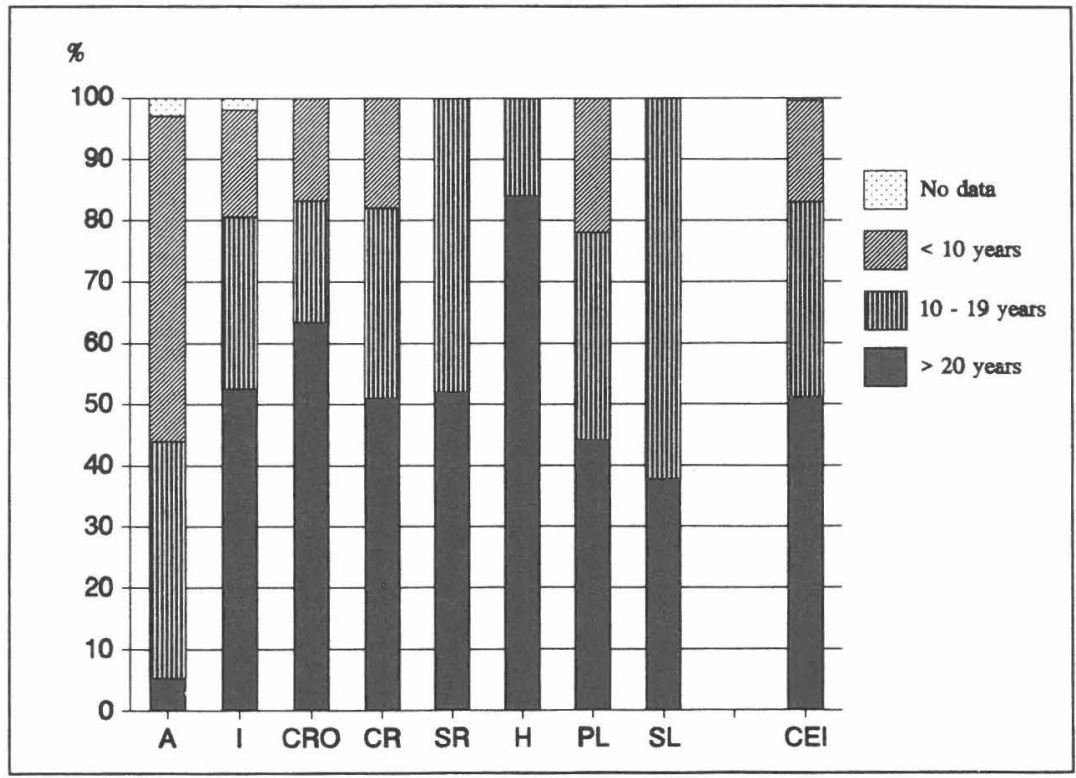

Fig. 9. $\mathrm{SO}_{2}$ emissions according to the age of boilers (public power plants only).

higher energy efficiency than the old boilers, thereby reducing the required volume of fuel input (e.g. coal) to produce the same amount of electricity. According to the CEI' 88 database most of the power plants in the former CMEA countries older than 20 years are operating with an efficiency of between 28 and $32 \%$. For new conventional plants, however, efficiencies range between 40 and $43 \%$. This means that when electricity demand is constant, just replacing old obsolete equipment with new installations (without 


\begin{tabular}{|c|c|c|c|c|}
\hline & Name of the Plant & Country & Region & hission ( $k$ Vyear) \\
\hline 1 & PPP Belchatow & Poland & Piotrkow Trybunalski & 341.6 \\
\hline 2 & PPP Prunerov & Czech Rep. & Northern Bohemia & 273.5 \\
\hline 3 & PPP Turow & Poland & Jelenia Gora & 205.4 \\
\hline 4 & PPP Tusimice & Czech Rep. & Northern Bohemia & 196.3 \\
\hline 5 & PPP Polaniec & Poland & Tarnobrzeg & 149.8 \\
\hline 6 & PPP Jaworzno III & Poland & Katowice & 131.4 \\
\hline 7 & PPP Pocerady & Czech Rep. & Northern Bohemia & 126.9 \\
\hline 8 & PPP & Italy & Roma & 123.9 \\
\hline 9 & PPP Kozienice & Poland & Radom & 116.2 \\
\hline 10 & PPP Kostolany & Slovak Rep. & Central Slovakia & 114.7 \\
\hline 11 & PPP Siersza & Poland & Katowice & 111.5 \\
\hline 12 & PPP Rybnik & Poland & Katowice & 97.1 \\
\hline 13 & PPP Gagarin & Hungary & Heves & 94.6 \\
\hline 14 & PPP Tisova & Czech Rep. & Western Bohemia & 86.2 \\
\hline 15 & Refinery & Italy & Messina & 85.1 \\
\hline 16 & PPP Sostanj & Slovenia & Slovenia & 84.7 \\
\hline 17 & PPP Patnow-Konin & Poland & Konin & 84.0 \\
\hline 18 & PPP & Italy & Rovigo & 80.3 \\
\hline 19 & PPP Melnik & Czech Rep. & Central Bohemia & 79.1 \\
\hline 20 & PPP Dolna Odra & Poland & Szczecin & 78.3 \\
\hline 21 & PPP Laziska & Poland & Katowice & 77.6 \\
\hline 22 & PPP Borsod & Hungary & Borsod-Abauj-Zemplen & 68.9 \\
\hline 23 & PPP Tisza & Hungary & Borsod-Abauj-Zemplen & 67.4 \\
\hline 24 & Refinery Plock & Poland & Plock & 67.3 \\
\hline \multirow[t]{2}{*}{25} & Chemopetrol & Czech Rep. & Northern Bohemia & 65.7 \\
\hline & Total & & & 3007.5 \\
\hline PTI & blic Power Plant & & & \\
\hline
\end{tabular}

Scheme 2. The 25 largest emitters of $\mathrm{SO}_{2}$ in the CEI region in 1988.

applying any emission control) could reduce $\mathrm{SO}_{2}$ emissions by $30-40 \%$. The application of standard emission control technologies (such as flue gas desulfurization) or fuel substitution could reduce emissions even further.

Particularly high emissions occur at many power plants in eastern Europe. The largest emitter, the power plant in Belchatow (Poland), emits $342 \mathrm{kt}$ of $\mathrm{SO}_{2}$, which is almost three times higher than all Austrian sources together $\left(116 \mathrm{kt} \mathrm{SO}_{2}\right)$. This is not an exception; there are nine additional plants identified in the inventory whose emissions surpass those of all of Austria. In total, 25 largest plants (out of the 402 LPS identified in the CEI' 88 inventory) are responsible for about $30 \%$ of total $\mathrm{SO}_{2}$ emissions in the CEI region (Scheme 2).

\section{Reliability and accuracy of the emission inventory}

The question of reliability of emission estimates is often cause for concern. Major factors influencing the accuracy of emission estimates are:

- quality of energy and emission data,

- data on fuel quality (sulphur content, calorific value, etc.),

- emission factors.

The quality of statistical material available varies from country to country. In some of the CEI countries, energy and emission statistics were incomplete for 1988. Therefore, appropriate statistics for other years were used. The margin of error, however, is expected to be small due to the fact that at that time economic changes were relatively slow. A more important source of inaccuracy is related to differences in classification of sectors in data provided by the national experts.

Fuel quality data, especially sulphur content and calorific value, are of great importance for all emission estimates. Data on the national level are usually consistent and reliable. However, calculations on the regional level, especially for the residential/commercial sector, are often based on incomplete data. This applies mainly to those countries where domestically produced solid fuels are used extensively in this sector, e.g. Poland, the Czech Republic and the Slovak Republic.

In this paper, $\mathrm{NO}_{x}$ emissions are based on data provided by the national experts. The underlying $\mathrm{NO}_{x}$ emission factors are generally in accordance with internationally accepted coefficients (Bouscaren, 1991). There are, however, some exceptions. In case of the Czech Republic and the Slovak Republic, emission factors applied in the national system for estimation of emissions of air pollutants (REZZO-Register of Emissions and Sources of Atmospheric Pollutants) (Jilek, 1992) result in emissions, in some cases, even $100 \%$ higher than emissions calculated using international emission factors.

For particulate matter emission, the values obtained for power plants are generally reliable. However, PM emissions for other sectors, especially estimates on the regional level, rely strongly on the avail- 
ability and the accuracy of fuel quality data as well as on estimates of efficiency of particulate control equipment. Again, this is a major concern in countries where solid fuels play a dominant role.

\section{CONCLUSIONS}

The emission inventory of the Central European Initiative (the CEI'88 inventory) described in this paper provides the first consistent overview of emissions of sulphur dioxide $\left(\mathrm{SO}_{2}\right)$, nitrogen oxides $\left(\mathrm{NO}_{x}\right)$, particulate matter (PM) and carbon dioxide $\left(\mathrm{CO}_{2}\right)$ of the region. The inventory describes the situation in the year 1988 for Austria, Croatia, Czechoslovakia (separated into the Czech and Slovak Republics), Hungary, Italy, Poland and Slovenia. The collected database provides the following:

- an estimate of the overall quantity of emissions (regionally disaggregated into 187 administrational units),

- a description of the most important techno-economic parameters of the main individual emission sources in the region (402 sources are considered).

The study shows that central Europe contributes substantially to total European emissions of air pollutants. The reasons for this dominant role are the high population density and the high level of economic activities occurring in the region. Even more important, however, are the high energy intensities of the former centrally planned economies, where energy is mainly supplied by the combustion of domestic solid fuels without appropriate emission control equipment.

The CEI' 88 inventory provides important information for in-depth analysis of air pollution, not only for central Europe, but, due to the long-range transport of pollutants, also for the whole of Europe. The information contained in the database is an essential element for designing of cost-effective strategies to reduce air pollution.

Acknowledgements-The authors are grateful for the financial support received from the Italian Ministry of the Environment for this study. The successful completion of this study would not have been possible without the close international co-operation of national experts from the following institutes: Umweltbundesamt (Vienna), National Meteorological
Institute (Zagreb), Czech Ministry of Environment (Prague), Slovak Hydrometeorological Institute (Bratislava), Power Research Institute (Bratislava), Institute for Environmental Protection (Budapest), Hungarian Power Companies Ltd (Budapest), Italian National Agency for New Technology Energy and Environment (ENEA) (Rome), The Institute for Fundamental Technological Research (Warsaw), Hydrometeorological Institute of Slovenia (Ljubljana), University of Karlsruhe (Karlsruhe), CEC-DGXI, Task Force Environmental Protection Agency (Brussels), WHO/ECEH (World Health Organization/European Center for Environment and Health), Bilthoven, Netherlands.

\section{REFERENCES}

Bouscaren M. R. (1991) Default Emission Factors Handbook (second edition). CORINAIR Inventory. CEC, CITEPA, Paris.

CEC (Commission of the European Communities) (1988) Nomenclatures. CORINAIR, Programme CORINE. CEC, 2 November 1988, Brussels.

CEC (Commission of the European Communities) (1991) Results of the CORINE Program. SEC (91) 958, May 1991, Brussels.

EUROSTAT (Statistical Office of the European Communities) (1991) REGIO Banque de données régionales (Description du contenu). EUROSTAT, Luxembourg.

EUROSTAT (Statistical Office of the European Communities) (1992) REGIONS, Nomenclature of Administrative Regions of Non-community Member States. Draft version 1.0, March 1992, EUROSTAT, Luxembourg.

Jelavic V., Stojak V. and Carevik M. (1992) Balance of emission of pollutants into the atmosphere from Croatian power utility thermal power plants. Energy Research and Environmental Protection Institute (EKONERG), Zagrels, Croatia.

Jilek P. (1992) Remarks on the Present State of Emissions Inventory in the CSFR. Research Institute of Fuel and Energy Complex, Prague (unpublished).

Klimont Z., Amann M., Cofala J., Gyarfas F., Klaassen G. and Schöpp W. (1993) Emission of air pollutants in the region of the Central European Initiative-1988. SR-93-3, IIASA, Laxenburg, Austria.

Pacyna J. M. (1988) NO $_{x}$ emissions from stationary sources in eastern Europe in 1985. NILU, 78/88, Lillestrom, Norway.

Pacyna J. M. (1989) Emissions of major air pollutants emitted in eastern Europe. NILU, 48/89, Lillestrom, Norway.

Pacyna J. M., Larssen S. and Semb A. (1989) European survey for $\mathrm{NO}_{x}$ emissions, 1985. NILU, 26/89, Lillestrom, Norway.

UNECE (United Nations Economic Commission for Europe) (1992) 1992 Annual review of Strategies and policies. UNECE, Geneva.

Veldt C. (1991) Emissions of $\mathrm{SO}_{x}, \mathrm{NO}_{x}, \mathrm{VOC}$, and CO from East European Countries. Atmospheric Environment 25A, $2683-2700$. 